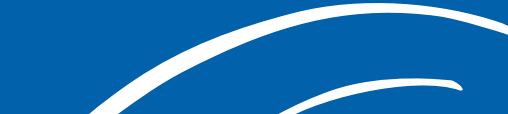 AGUA Y TERRITORIO
}

\section{La gestión participativa del agua en México (2002-2012): El caso de San Agustín Amatlipac (Morelos)}

\author{
Participatory water management in Mexico (2002-2012): \\ The case of St. Augustine Amatlipac (Morelos)
}

\author{
María A. de los Á. Guzmán-Puente \\ Universidad Autónoma del Estado de Morelos. Cuernavaca, México. angelesg@uaem.mx
}

Resumen - Este artículo expone la gestión participativa en el rubro agua y saneamiento en una comunidad del estado de Morelos, México, a la luz de las políticas públicas latinoamericanas en un contexto mundial. Dicha temática se aborda desde una reflexión sobre el papel de las instituciones internacionales formales que intervienen en países como México en sus programas de agua y saneamiento, y el rol que han jugado los grupos comunitarios en los programas de ejecución. Específicamente se trata el caso de la comunidad de San Agustín Amatlipac, Tlayacapan, Morelos. Nos centramos en el período $2002-2012$ usando la metodología participativa de interacción con los pobladores de la comunidad, a través de talleres de participación, entrevistas a profundidad e historias de vida. La interacción con un grupo universitario promotor del saneamiento participativo ha generado efectos no esperados, como la aplicación de programas de Estado a través de empresas privadas, situación no tan adversa que ha servido para reflexionar y aprender que un resultado sorpresivo puede ser integrado dentro del proceso prometedor de una concientización que busca mejorar el saneamiento participativo.

Abstract - This article considers participatory management of water and sanitation in a community in the Mexican state of Morelos in light of Latin American public policies located in a global context. This topic is approached through a reflection on the role played in Mexico by international institutions involved in water and sanitation programs, focusing more specifically on San Agustin Amatlipac, Tlayacapan, in the state of Morelos. This study based on fieldwork conducted between 2002 and 2012 reflects a participatory methodology of interaction with local communities through workshops, conducting in-depth interviews and recording life stories. It was found that interaction with a university group that promotes participatory practice in sanitation has produced unexpected results, such as the intervention of private enterprises that have, contrary to expectations not generated adverse reactions. This situation has served to provide a context in which to reflect on, and learn from, the ways in which an unanticipated result can be integrated into a promising process of consciousness raising and improvement in community management of water and sanitation.

Palabras clave: abastecimiento de agua, gestión participativa, San Agustín Amatlipac, Tlayacapan, Morelos, México Keywords: water supply, participatory management, San Agustín Amatlipac, Tlayacapan, Morelos, México

Códigos JEL: R11, R14, Q25, Q56. 